\title{
Atovaquone, chloroquine, primaquine, quinine and tetracycline: antiproliferative effects of relevant antimalarials on Neospora caninum
}

\author{
Atovaquona, cloroquina, primaquina, quinino e tetraciclina: efeitos \\ antiproliferativos de antimaláricos relevantes em Neospora caninum
}

Luiz Miguel Pereira'; Gabriela de Luca; Nathália de Lima Martins Abichabki'; Jade Cabestre Venancio Brochi'; Luciana Baroni"; Péricles Gama Abreu-Filho'; Ana Patrícia Yatsuda1* (1)

${ }^{1}$ Departamento de Análises Clínicas, Toxicológicas e Bromatológicas, Faculdade de Ciências Farmacêuticas de Ribeirão Preto, Universidade de São Paulo - USP, Ribeirão Preto, SP, Brasil

How to cite: Pereira LM, Luca G, Abichabki NLM, BrochiJCV, Baroni L, Abreu-Filho PG, et al. Atovaquone, chloroquine, primaquine, quinine and tetracycline: Antiproliferative effects of relevant antimalarials on Neospora caninum. Braz J Vet Parasito/ 2021; 30(1): e022120. https://doi.org/10.1590/S1984-29612021006

\begin{abstract}
Neospora caninum is an apicomplexan parasite that causes abortion in cattle, resulting in significant economic losses. There is no commercial treatment for neosporosis, and drug repositioning is a fast strategy to test possible candidates against $N$. caninum. In this article, we describe the effects of atovaquone, chloroquine, quinine, primaquine and tetracycline on $\mathrm{N}$. caninum proliferation. The $\mathrm{IC}_{50}$ concentrations in $\mathrm{N}$. caninum were compared to the current information based on previous studies for Plasmodium and Toxoplasma gondii, correlating to the described mechanisms of action of each tested drug. The inhibitory patterns indicate similarities and differences among N. caninum, Plasmodium and T. gondii. For example, atovaquone demonstrates high antiparasitic activity in all the analyzed models, while chloroquine does not inhibit N. caninum. On the other hand, tetracycline is effective against Plasmodium and $N$. caninum, despite its low activity in $T$. gondii models. The repurposing of antimalarial drugs in N. caninum is a fast and inexpensive way to develop novel formulations using well-established compounds.
\end{abstract}

Keywords: Neospora caninum, atovaquone, chloroquine, quinine, primaquine, tetracycline.

\begin{abstract}
Resumo
Neospora caninum é um parasita Apicomplexa relacionado a abortos no gado bovino, que resultam em impactos econômicos. Não há tratamento comercial para neosporosis e o reposicionamento de drogas indica uma estratégia rápida para testar candidatos anti- $N$. caninum. Neste artigo, são descritos os efeitos da atovaquona, cloroquina, quinino, primaquine e tetraciclina na proliferação de $N$. caninum. As concentrações $I_{50} \mathrm{em} \mathrm{N}$. caninum foram comparadas com a informação disponível, baseada em estudos publicados previamente para Plasmodium e Toxoplasma gondii, incluindo a correlação com os mecanismos de ação descritos para cada droga testada. Os padrões de inibição indicam pontos de similaridades e diferenças entre $N$. caninum, Plasmodium e $T$. gondii. Por exemplo, a atovaquona demonstra uma alta atividade antiparasitária em todos os modelos testados, enquanto a cloroquina não inibe N. caninum. Por outro lado, a tetraciclina é efetiva contra Plasmodium e N. caninum, em contraste com a baixa atividade em modelos de $T$. gondii. O reposicionamento de drogas antimaláricas em $N$. caninum é uma forma rápida e de baixo custo para o desenvolvimento de novas formulações que usam compostos bem estabelecidos.
\end{abstract}

Palavras-chave: Neospora caninum, atovaquona, cloroquina, quinino, primaquine, tetraciclina. 


\section{Introduction}

Neospora caninum is an obligate intracellular protozoan and a member of the phylum Apicomplexa. Canids are the definitive host of $N$. caninum, while ruminants are infected by the non-sexual forms of the parasite (Dubey \& Schares, 2011; Marugan-Hernandez, 2017). In intermediate hosts, neosporosis causes abortion and impairs fertility, thus strongly affecting livestock productivity (Reichel et al., 2013).

There is no commercial strategy to control neosporosis, despite the recent advances (Anghel et al., 2018; Harmse et al., 2017; Pereira et al., 2020; Sánchez-Sánchez et al., 2018a, b) and the development of management control measures designed to reduce parasite transmission (Reichel et al., 2014). Likewise, there are few options for the treatment of human toxoplasmosis, which is usually treated with compounds (antifolates, clindamycin, and atovaquone) that are toxic, especially to pregnant women (Neville et al., 2015). On the other hand, there is an arsenal of drugs against malaria, targeted to various stages of the parasite, which were developed in response to the side effects (i.e., blue urine and sclera in methylene blue treated patients) or cases of resistance (artemisinin, pyrimethamine, chloroquine) (Bosson-Vanga et al., 2018; Luzzi \& Peto, 1993; Takala-Harrison \& Laufer, 2015; Wadi et al., 2018). Thus, the application of anti-malarial drugs indicates an interesting source for drug repurposing against $N$. caninum. For example, methylene blue and analogues, pyrimethamine and artemisinin formulations have been successfully tested on in vitro (Kim et al., 2002; Lindsay \& Dubey, 1989; Pereira et al., 2017, 2018) and in vivo (Pereira et al., 2020) models of $N$. caninum infection. Likewise, several novel candidates with anti-N. caninum activity were identified from the Malaria Venture (MMV) Pathogen Box, with promising results (Müller et al., 2017, 2020). Moreover, antimalarial drugs also demonstrate activity against T. gondii (Holfels et al., 1994; Kadri et al., 2014; Kim et al., 2002; Lindsay et al., 1994; McFadden et al., 1997; Secrieru et al., 2020). As members of the same phylum (Apicomplexa), there are several similarities among N. caninum, Plasmodium and T. gondii (Morrissette \& Sibley, 2002; Reid et al., 2012), which was also observed when drugs were evaluated.

In this study, the widely used antimalarials quinine, chloroquine, primaquine and atovaquone were tested against $N$. caninum using LacZ-tagged tachyzoites and were compared with the current information (based on previous studies) about Plasmodium and T. gondii, reinforcing the similarities and differences among them. This will underpin the development of common or exclusive therapeutic strategies based on drug repurposing.

\section{Material and Methods}

\section{N. caninum culture}

N. caninum tachyzoites (NC1-LacZ) (Pereira \& Yatsuda, 2014) were maintained in Vero cells monolayers with $100 \mu \mathrm{g} / \mathrm{mL}$ kanamycin. The Vero cells and parasites were cultured in RPMI-1640 and RPMI-1640 supplemented with $5 \%$ fetal calf serum (Sigma), respectively. The tachyzoites were purified from the culture supernatants using a $5 \mu \mathrm{M}$ syringe filter and counted in a hemocytometer.

\section{Drugs}

All the drugs used in this study were purchased from Sigma-Aldrich (St. Louis, MO, USA). Atovaquone (10 mg/mL, catalogue number: A7986), primaquine $(100 \mathrm{mg} / \mathrm{mL}$, catalogue number: 160393$)$ and tetracycline $(20 \mathrm{mg} / \mathrm{mL}$, catalogue number: T7660) were diluted in DMSO (Sigma-Aldrich), while chloroquine $(10 \mathrm{mg} / \mathrm{mL}$, catalogue number: C6628) and quinine (10 mg/mL, catalogue number: 145904) were diluted in PBS.

\section{Antiproliferative assay}

The antiproliferative assay was performed as described by Pereira et al. (2017), using a chlorophenol red- $\beta$-D-galactopyranoside (CPRG, Sigma-Aldrich) based assay. Briefly, the purified tachyzoites $\left(5 \times 10^{3} /\right.$ well) were distributed in 96-well plates with Vero cell monolayers and incubated for $2 \mathrm{~h}, 37^{\circ} \mathrm{C}, 5 \% \mathrm{CO}_{2}$ to allow the invasion. Seven serial dilutions of drugs (1:2) were incubated, in triplicate, for $72 \mathrm{~h}, 37^{\circ} \mathrm{C}, 5 \% \mathrm{CO}_{2}$. The initial concentrations of atovaquone, chloroquine, quinine, primaquine, and tetracycline were $100 \mathrm{nM}, 1 \mathrm{mM}, 1 \mathrm{mM}, 100 \mu \mathrm{M}$ and $100 \mu \mathrm{M}$, respectively (Figure 1). After treatment, the cells were washed with PBS and lysed with $125 \mu \mathrm{L}$ CPRG lysis buffer (100 mM 4- (2-hydroxyethyl)-1-piperazineethanesulfonic acid, pH 8.0; 1 mM CaCl2; $1 \%$ Triton X-100, 0.5\% SDS; $5 \mathrm{mM}$ DTT) for $1 \mathrm{~h}$ at $50^{\circ} \mathrm{C}$. The lysates were incubated with $125 \mu \mathrm{L}$ of CPRG buffer ( $5 \mathrm{mM} \mathrm{CPRG}$ and $50 \mathrm{mM} \mathrm{MgSO}_{4}$ in lysis buffer) for $4 \mathrm{~h}$ at $37^{\circ} \mathrm{C}$ and the plates analyzed at $570 \mathrm{~nm}$ in a spectrophotometer (Sunrise, Tecan). Three independent assays were performed for each drug. 

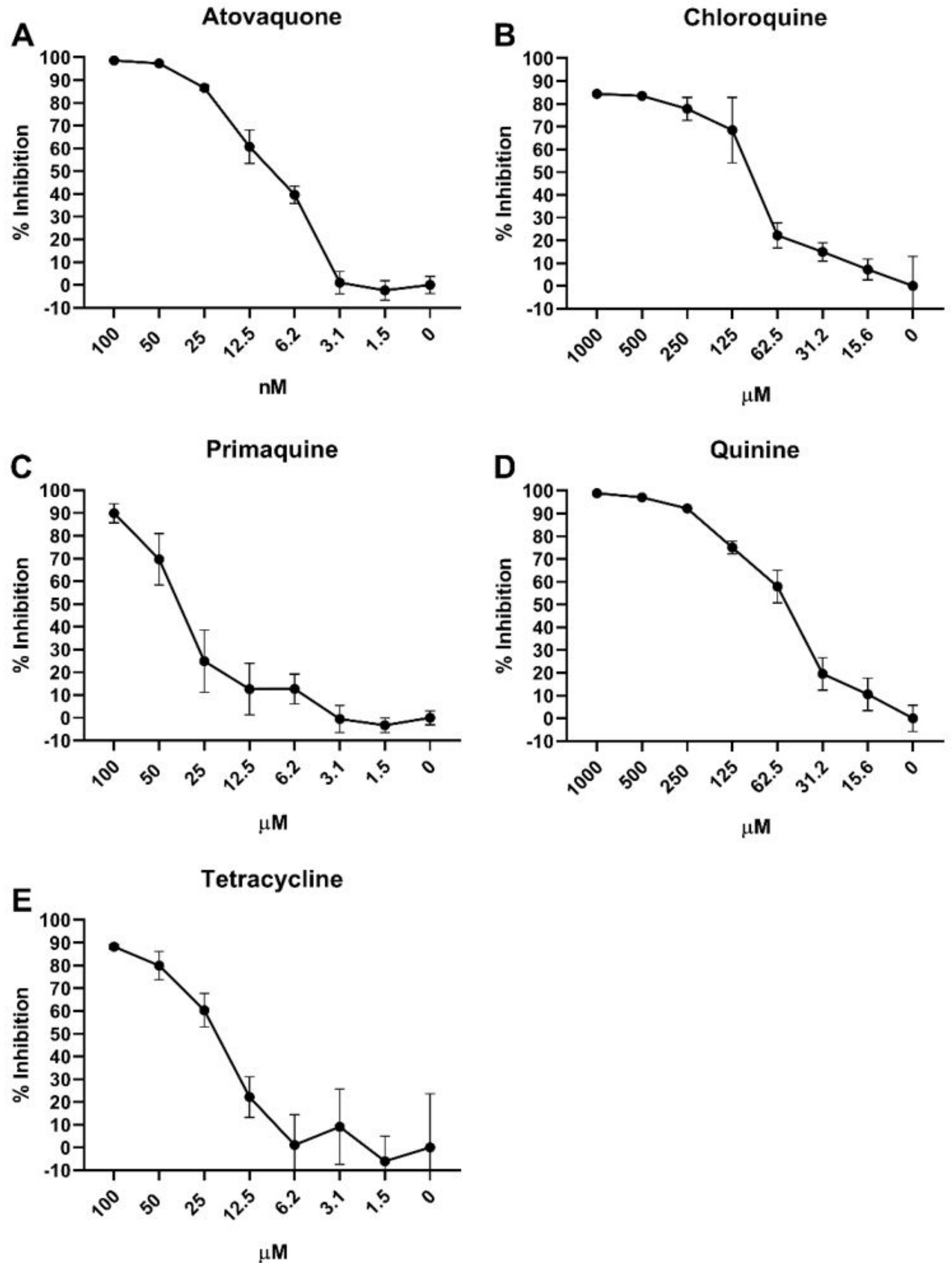

Figure 1. Dose-inhibitory curves of antimalarials against $N$. caninum. $N$. caninum tachyzoites in Vero cells were incubated for $72 \mathrm{~h}$ with seven serial dilutions of atovaquone (100-1.5 $\mathrm{nM})$, chloroquine (1000-15.6 $\mu \mathrm{M})$, primaquine $(100-1.5 \mu \mathrm{M})$, quinine (1000-15.6 $\mu \mathrm{M})$ and tetracycline (100-1.5 $\mu \mathrm{M})$. After incubation, the parasite proliferation was measured by CPRG assay and the percentage of inhibition was calculated in relation to the non-treated controls. The percentage of inhibition values were plotted in relation to the drug concentrations using the GraphPad Prism 5 software. 


\section{Cytotoxicity}

The cytotoxicity of the antimalarial drugs on Vero cells was evaluated by MTT assay (Mosmann, 1983). The drugs were incubated in 96-well plates for $72 \mathrm{~h}, 37^{\circ} \mathrm{C}, 5 \% \mathrm{CO}_{2}$ on confluent monolayers of Vero cells in phenol red-free RPMI. After incubation, the supernatant was carefully discarded and the wells were incubated with $100 \mu \mathrm{L}$ of MTT solution $(500 \mu \mathrm{g} / \mathrm{mL})$ for $4 \mathrm{~h}, 37^{\circ} \mathrm{C}$, followed by the dilution of formazan crystals with DMSO (Sigma). The plates were read in a spectrophotometer at $570 \mathrm{~nm}$ and the percentage of cytotoxicity was calculated (Pereira et al., 2017). The drugs were initially diluted at $20 \mu \mathrm{M}$ (atovaquone), $1 \mathrm{mM}$ (chloroquine), $2 \mathrm{mM}$ (quinine), $1 \mathrm{mM}$ (primaquine) and $1 \mathrm{mM}$ (tetracycline). Three independent assays were performed for each drug.

\section{Statistical analysis}

The percentage of proliferation inhibition and toxicity were calculated using the formula (( $\mathrm{ABS}_{\text {control }}-\mathrm{ABS}_{\text {sample }} /$ $\left.\left.A B S_{\text {control }}\right) * 100\right)$, where $A B S_{\text {control }}$ and $A B S_{\text {sample }}$ represent the mean absorbance of the drug-free control and the absorbance from each drug treatment, respectively. The $\mathrm{IC}_{50}$ (parasite inhibition) and $\mathrm{CC}_{50}$ (Vero cell toxicity) were calculated from the proliferation/toxicity percentages using CompuSyn software (CompuSyn, 2017; Chou, 2010). The selective index $\left(\mathrm{CC}_{50} / \mathrm{IC}_{50}\right)$ was also calculated from the $I \mathrm{C}_{50}$ and $\mathrm{CC}_{50}$ values. The values are presented as the mean of three independent tests \pm SD, calculated using the Graphpad Prism 5 software.

\section{Results and Discussion}

Among the tested antimalarials, atovaquone showed the lowest $\mathrm{IC}_{50}$ for $\mathrm{N}$. caninum $(0.008 \mu \mathrm{M}$, Table 1 and Figure 1A). This concentration was similar to that reported for Plasmodium (0.0007-0.0018 $\mu \mathrm{M}$ ) (Basco et al., 1995) and T. gondii (0.007-0.021 M) (McFadden et al., 1997). Atovaquone combined with proguanil (registered as Malarone $\left.{ }^{\circledR}\right)$ has been used for the treatment of uncomplicated malaria in non-endemic countries and as a preventive strategy for travelers (Thybo et al., 2004). Atovaquone has also exhibited promising results against retinochoroiditis caused by T. gondii (Harrell \& Carvounis, 2014; Pearson et al., 1999). In the Plasmodium model, the molecule causes the mitochondria to collapse, inhibiting electron transport through the cytochrome bc complex (Mather et al., 2005). Indeed, the mutation in the cytochrome bc1 complex is causally associated with atovaquone resistance in malaria patients (Staines et al., 2018). Despite the low $\mathrm{CC}_{50}$ of atovaquone in Vero cells $(3.3 \mu \mathrm{M})$, the drug is usually welltolerated (Baggish \& Hill, 2002). For example, the CC $_{50}$ for HEK293T (human embryonic kidney) is $43 \mu \mathrm{M}$ (Schuck et al., 2013), indicating a higher susceptibility of Vero cells to the drug, fact also observed in several cell lines of breast cancer ( $\mathrm{CC}_{50}: 11-18 \mu \mathrm{M}$ ) (Gupta \& Srivastava, 2019). Indeed, there is a report of atovaquone related nephrotoxicity in allogeneic transplanted patients (Mendorf et al., 2015), indicating the susceptibility of some cells of renal origin. As observed in toxoplasmosis and malaria, atovaquone has an interesting potential against neosporosis. Further studies should elucidate the mechanisms of action.

Quinine, chloroquine and primaquine are members of the quinolone family, which have traditionally been used to treat malaria. Quinine was originally extracted from the bark of the Cinchona (quina-quina) tree, used by native inhabitants of South America for the alleviation of malaria symptoms (Achan et al., 2011). The compound

Table 1. Parasite inhibitory $\left(\mathrm{IC}_{50}\right)$ and cytotoxic $\left(\mathrm{CC}_{50}\right)$ doses of antimalarials in N. caninum. Purified N. caninum (lacZ) tachyzoites were distributed in Vero cell monolayers and incubated with serial dilutions of atovaquone, chloroquine, primaquine, quinine and tetracycline. Proliferation was evaluated by CPRG. In parallel, the cytotoxicity on Vero cells was determined by MTT under the same conditions. The $\mathrm{IC}_{50}$ and $\mathrm{CC}_{50}$ concentrations were calculated from dose response-curves, using CompuSyn software. SI: Selectivity index.

\begin{tabular}{cccr}
\hline & N. caninum $I C_{50}(\mu \mathrm{M})$ & Vero cell $\mathrm{CC}_{50}(\mu \mathrm{M})$ & $\mathrm{SI}$ \\
\hline Atovaquone & $0.008( \pm 0.002)$ & $3.3( \pm 1.1)$ & 412.5 \\
Chloroquine & $112.6( \pm 39.4)$ & $483.5( \pm 253.7)$ & 4.2 \\
Primaquine & $44.4( \pm 17.0)$ & $>1000$ & $>22.5$ \\
Quinine & $56.6( \pm 11.7)$ & $508.5( \pm 155.4)$ & 8.9 \\
Tetracycline & $19.6( \pm 3.3)$ & $>500$ & $>25.5$ \\
\hline
\end{tabular}


was isolated by Pierre Joseph Pelletier and Joseph Caventou in 1820 (Krettli, 2001) and completely synthesized in 1945 by Woodward \& Doering (1945). Quinine has long been used to treat malaria. However, the drug has been replaced by artesunate or artemether (Esu et al., 2019). Interestingly, quinine has different effects against Plasmodium and T. gondii. Although quinine shows high activity in in vitro models of Plasmodium $(0.272-5.2 \mu \mathrm{M}$, and 0.053-8.1 $\mu \mathrm{M}$ determined by (Touré et al., 2008), (Björkman et al., 1991) and (Menezes et al., 2001), no inhibitory effect on T. gondii has been reported (Gomes et al., 2012; Holfels et al., 1994). Against N. caninum, the activity of quinine was moderate (56.6 $\mu \mathrm{M}$, Table 1 and Figure 1D).

The manipulation of the methylene blue structure generated pamaquine and quinaquine, the basic compounds for the synthesis of primaquine and chloroquine, respectively (Al-Bari, 2015). Eventually, methylene blue was replaced with chloroquine, mainly due to the absence of visible side effects (green urine and sclera) of the phenothiazinium dyes (Ginimuge \& Jyothi, 2010). Moreover, no activity of methylene blue on hepatic stages of Plasmodium sp. was observed, including hypnozoites (Bosson-Vanga et al., 2018), in contrast to its effective in vitro activity against $N$. caninum (Pereira et al., 2017). Currently, the use of chloroquine is restricted to non-complicated malaria in regions with no prevalence of drug resistance (Mwanza et al., 2016). Primaquine is used to prevent the relapse of Plasmodium vivax and has the unique ability to eliminate the gametocyte form of Plasmodium falciparum (Ashley et al., 2014). Chloroquine susceptible strains of Plasmodium are usually inhibited in doses below 0.1 MM (Aguiar et al., 2014; Chehuan et al., 2013; Fall et al., 2015). In Brazil, the recommended treatment for Plasmodium vivax ( $83.6 \%$ of the reported cases) is based on primaquine and chloroquine combinations to control the hypnozoite and trophozoite forms, respectively (Brasil, 2010; Negreiros et al., 2016). Chloroquine is also active against $T$. gondii, with an $\mathrm{IC}_{50}$ of $2.25 \mu \mathrm{M}$ (Kadri et al., 2014). However, chloroquine showed a robust inhibitory effect against $N$. caninum only at concentrations above $100 \mu \mathrm{M}$ (Table 1 and Figure 1B). Similarly to quinine, primaquine inhibited N. caninum at $44.4 \mu \mathrm{M}$ (Table 1 and Figure 1C), whereas no effect has been reported against $T$. gondii (Holfels et al., 1994). On the other hand, Plasmodium falciparum exhibits higher susceptibility to primaquine ( $\left(\mathrm{C}_{50}\right.$ range; 0.46-18.9 $\mu \mathrm{M}$ ) than N. caninum (Basco et al., 1999; Cabrera \& Cui, 2015). Although formulations containing quinine, chloroquine or primaquine have been applied in malaria therapy for more than 50 years, the mechanisms of action are not completely established. The suggested mechanism for quinine and chloroquine is based on the prevention of heme polymerization, converting the toxic molecule to hemozoin (Sullivan et al., 1996). The mechanism of primaquine is not fully understood, but the drug probably interferes with the cellular respiration in Plasmodium, which generates oxygen free radicals and deregulates the electron transport (Fernando et al., 2011). The quinolones showed different effects on N. caninum, Plasmodium and T. gondii, indicating species-specific targets. Firstly, the erythrocyte cycle is absent in $N$. caninum and $T$. gondii, requiring future assays to elucidate the mechanism of quinine and chloroquine in coccidian members. The higher activity of quinine and primaquine in $N$. caninum compared to $T$. gondii indicates an interesting group of drugs for the control of neosporosis, with independent strategies compared to toxoplasmosis models. Moreover, there is a wide range of available quinolone derivatives (Chu et al., 2019; Gao et al., 2019; Hu et al., 2017; Wang et al., 2019), amplifying the candidate list for testing against $N$. caninum.

Tetracycline was active against $N$. caninum $\left(\mathrm{IC}_{50} 19.6 \mu \mathrm{M}\right.$, Table 1 and Figure $1 \mathrm{E}$ and ineffective against $T$. gondii at concentrations above $40 \mu \mathrm{g} / \mathrm{mL}(83.1 \mu \mathrm{M})$ (Chang et al., 1990). Moreover, tetracycline analogues (doxycycline and minocycline) have demonstrated high activity against $N$. caninum, blocking $100 \%$ of the parasite proliferation at doses $>2 \mu \mathrm{M}$ (Lindsay et al., 1994). For Plasmodium, tetracycline inhibits $50 \%$ of in vitro proliferation at concentrations below $9.8 \mu \mathrm{M}$ (Ye \& Van Dyke, 1994). The drug and derivatives (i.e., doxycycline) are applied as slow-acting blood schizonticidal agents in formulations for the treatment of uncomplicated malaria, usually in combination with quinine (Dahl et al., 2006; Gaillard et al., 2015). Tetracycline has an antagonist affinity at the 30 S ribosomal subunit of prokaryotes, preventing the attachment of aminoacyl tRNA to the acceptor (A) site of the organelle (Chopra \& Roberts, 2001). In Plasmodium, the inhibitory effect of tetracycline is also observed on ribosomes of the parasite apicoplast, inducing the delayed death mechanism (Fichera \& Roos, 1997; Ramya et al., 2007; Uddin et al., 2017), and occurs mainly after a cycle of egress and invasion (Botté et al., 2012; Uddin et al., 2017). Apicoplast is an exclusive organelle of the phylum Apicomplexa with a prokaryotic origin and houses singular and essential metabolic pathways to the parasite's survival and virulence, representing a promising target for the control of apicomplexan diseases (Biddau \& Sheiner, 2019; Dahl et al., 2006). The differential susceptibility to tetracycline suggests divergences among the apicoplast metabolism of N. caninum, Plasmodium and T. gondii (Haussig et al., 2011). Although the tetracycline delayed death process is well documented in Plasmodium, further experiments are needed to evaluate this phenomenon in N. caninum and T. gondii. 
Excepting atovaquone, all antimalarials tested demonstrated low toxicity in Vero cells ( $\left.\mathrm{CC}_{50} \geq 483.5 \mu \mathrm{M}\right)($ Table 1$)$. Chloroquine, primaquine, quinine and tetracycline usually lead to toxicity in non-tumoral lineages at concentrations above $51 \mu \mathrm{M}, 395 \mu \mathrm{M}, 200 \mu \mathrm{M}$ and $225 \mu \mathrm{M}$, respectively (Lelièvre et al., 2012; Davanço et al., 2014; Sanders et al., 2014; Ou at al., 2019). However, we must consider that the $\mathrm{CC}_{50}$ concentrations vary depending on the cell lineage employed (Florento et al., 2012). Therefore, novel assays focusing on the cytotoxicity on different cells lineages, especially from bovine and canine models, are mandatory to elucidate the safety of antimalarials for the control of neosporosis.

The tested antimalarials (Figure 2) exhibited several similarities and differences against N. caninum, Plasmodium and $T$. gondii, contributing to a specific comprehension of the metabolic mechanisms of each parasite. Our results indicate the potential of atovaquone for use in in vivo assays, as well as the demand for investigating effective analogues of chloroquine, primaquine, quinine and tetracycline. The repurposing of antimalarials against $T$. gondii and $N$. caninum is an interesting way to obtain fast and low-cost candidates, since there is a vast body of information about their efficacy and toxicity in Plasmodium models (Müller et al., 2017, 2020). The comparison between these related parasites is a valid methodology, which will guide common or exclusive treatment regimens against neosporosis, malaria and toxoplasmosis.
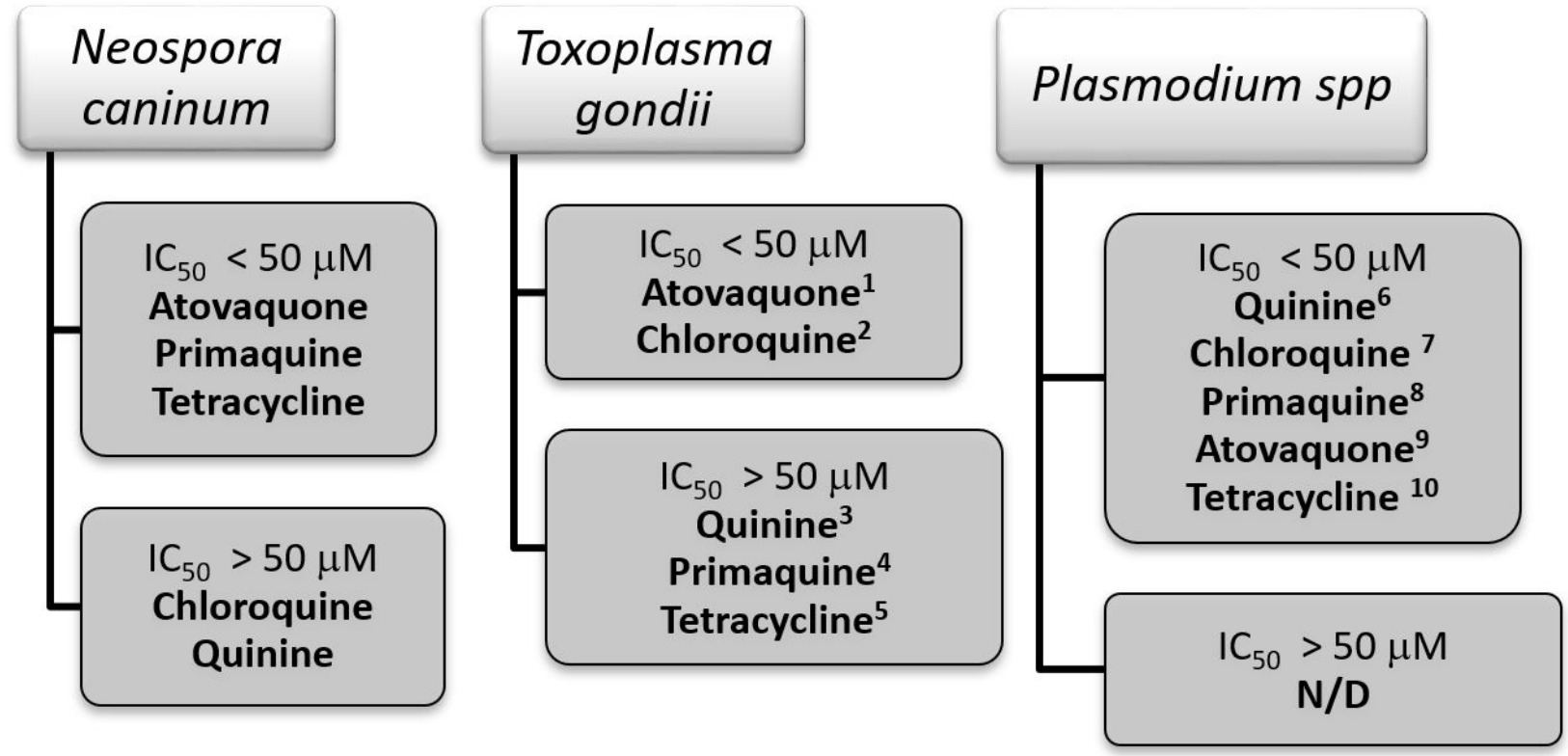

Figure 2. Schematic illustration of the antimalarial inhibition pattern on N. caninum, T. gondii and Plasmodium. Antimalarial drugs tested on N. caninum in this study (atovaquone, primaquine, tetracycline, chloroquine and quinine) were grouped according to their inhibitory pattern. Compounds with an $\mathrm{IC}_{50}>50 \mu \mathrm{m}$ were separated from those with higher inhibitory activity $\left(\mathrm{IC} \mathrm{C}_{50}<50 \mu \mathrm{m}\right)$. This classification was also applied to the same compounds with reported assays against T. gondii and Plasmodium. ${ }^{1}$ McFadden et al. (1997); ${ }^{2}$ Kadri et al. (2014); ${ }^{3,4} \mathrm{Holfels}$ et al. (1994); ${ }^{5} \mathrm{Chang}$ et al. (1990); ${ }^{6} \mathrm{Björkman}$ et al. (1991); ${ }^{7} \mathrm{Chehuan}$ et al. (2013); ${ }^{8} \mathrm{Basco}$ et al. (1999); ${ }^{9}$ Basco et al. (1995); ${ }^{10}$ Ye \& Van Dyke (1994). N/D: no data.

\section{Acknowledgements}

We would like to thank the Brazilian research funding agency CAPES (Federal Agency for the Support and Improvement of Higher Education) for the Postdoctoral fellowship (PNPD) awarded to LMP, and Ms. Maraísa Palhão Verri for her invaluable technical assistance.

\section{References}

Achan J, Talisuna AO, Erhart A, Yeka A, Tibenderana JK, Baliraine FN, et al. Quinine, an old anti-malarial drug in a modern world: role in the treatment of malaria. Malar J 2011; 10(1): 144. http://dx.doi.org/10.1186/1475-2875-10-144. PMid:21609473. 
Aguiar ACC, Pereira DB, Amaral NS, De Marco L, Krettli AU. Plasmodium vivax and Plasmodium falciparum ex vivo susceptibility to anti-malarials and gene characterization in Rondônia, West Amazon, Brazil. Malar J 2014; 13(1): 73. http://dx.doi.org/10.1186/14752875-13-73. PMid:24581308.

Al-Bari MAA. Chloroquine analogues in drug discovery: new directions of uses, mechanisms of actions and toxic manifestations from malaria to multifarious diseases. J Antimicrob Chemother 2015; 70(6): 1608-1621. http://dx.doi.org/10.1093/jac/dkv018. PMid:25693996.

Anghel N, Balmer V, Müller J, Winzer P, Aguado-Martinez A, Roozbehani M, et al. Endochin-like quinolones exhibit promising efficacy against Neospora caninum in vitro and in experimentally infected pregnant mice. Front Vet Sci 2018; 5: 285. http://dx.doi. org/10.3389/fvets.2018.00285. PMid:30510935.

Ashley EA, Recht J, White NJ. Primaquine: the risks and the benefits. Malar J 2014; 13(1): 418. http://dx.doi.org/10.1186/14752875-13-418. PMid:25363455.

Baggish AL, Hill DR. Antiparasitic agent atovaquone. Antimicrob Agents Chemother 2002; 46(5): 1163-1173. http://dx.doi.org/10.1128/ AAC.46.5.1163-1173.2002. PMid:11959541.

Basco LK, Bickii J, Ringwald P. In-vitro activity of primaquine against the asexual blood stages of Plasmodium falciparum. Ann Trop Med Parasitol 1999; 93(2): 179-182. http://dx.doi.org/10.1080/00034983.1999.11813408. PMid:10474643.

Basco LK, Le Bras J, Ramiliarisoa O. In vitro activity of atovaquone against the African isolates and clones of Plasmodium falciparum. Am J Trop Med Hyg 1995; 53(4): 388-391. http://dx.doi.org/10.4269/ajtmh.1995.53.388. PMid:7485692.

Biddau M, Sheiner L. Targeting the apicoplast in malaria. Biochem Soc Trans 2019; 47(4): 973-983. http://dx.doi.org/10.1042/ BST20170563. PMid:31383817.

Björkman A, Willcox M, Marbiah N, Payne D. Susceptibility of Plasmodium falciparum to different doses of quinine in vivo and to quinine and quinidine in vitro in relation to chloroquine in Liberia. Bull World Health Organ 1991; 69(4): 459-465. PMid:1934240.

Bosson-Vanga H, Franetich JF, Soulard V, Sossau D, Tefit M, Kane B, et al. Differential activity of methylene blue against erythrocytic and hepatic stages of Plasmodium. Malar J 2018; 17(1): 143. http://dx.doi.org/10.1186/s12936-018-2300-y. PMid:29615050.

Botté CY, Dubar F, McFadden GI, Maréchal E, Biot C. Plasmodium falciparum apicoplast drugs: targets or off-targets? Chem Rev 2012; 112(3): 1269-1283. http://dx.doi.org/10.1021/cr200258w. PMid:22026508.

Brasil. Ministério da Saúde. Guia prático de tratamento da malária no Brasil [online]. Brasília; 2010 [cited 2020 Aug 20]. Available from: http://bvsms.saude.gov.br/bvs/publicacoes/guia_pratico_malaria.pdf

Cabrera M, Cui L. In Vitro activities of primaquine-schizonticide combinations on asexual blood stages and gametocytes of Plasmodium falciparum. Antimicrob Agents Chemother 2015; 59(12): 7650-7656. http://dx.doi.org/10.1128/AAC.01948-15. PMid:26416869.

Chang HR, Comte R, Pecheère JC. In vitro and in vivo effects of doxycycline on Toxoplasma gondii. Antimicrob Agents Chemother 1990; 34(5): 775-780. http://dx.doi.org/10.1128/AAC.34.5.775. PMid:2360817.

Chehuan YF, Costa MRF, Costa JS, Alecrim MGC, Nogueira F, Silveira H, et al. In vitro chloroquine resistance for Plasmodium vivax isolates from the Western Brazilian Amazon. MalarJ 2013; 12(1): 226. http://dx.doi.org/10.1186/1475-2875-12-226. PMid:23819884.

Chopra I, Roberts M. Tetracycline antibiotics: mode of action, applications, molecular biology, and epidemiology of bacterial resistance. Microbiol Mol Biol Rev 2001; 65(2): 232-260. http://dx.doi.org/10.1128/MMBR.65.2.232-260.2001. PMid:11381101.

Chou TC. Drug combination studies and their synergy quantification using the Chou-Talalay method. Cancer Res 2010; 70(2): 440-446. http://dx.doi.org/10.1158/0008-5472.CAN-09-1947. PMid:20068163.

Chu XM, Wang C, Liu W, Liang LL, Gong KK, Zhao CY, et al. Quinoline and quinolone dimers and their biological activities: an overview. Eur J Med Chem 2019; 161: 101-117. http://dx.doi.org/10.1016/j.ejmech.2018.10.035. PMid:30343191.

CompuSyn. [online]. 2017. [cited 2017 Sept 20]. Available from: https://www.combosyn.com/.

Dahl EL, Shock JL, Shenai BR, Gut J, DeRisi JL, Rosenthal PJ. Tetracyclines specifically target the apicoplast of the malaria parasite Plasmodium falciparum. Antimicrob Agents Chemother 2006; 50(9): 3124-3131. http://dx.doi.org/10.1128/AAC.00394-06. PMid:16940111.

Davanço MG, Aguiar AC, Santos LA, Padilha EC, Campos ML, Andrade CR, et al. Evaluation of antimalarial activity and toxicity of a new primaquine prodrug. PLoS One 2014; 9(8): e105217. http://dx.doi.org/10.1371/journal.pone.0105217. PMid:25133630.

Dubey JP, Schares G. Neosporosis in animals: the last five years. Vet Parasito/ 2011; 180(1-2): 90-108. http://dx.doi.org/10.1016/j. vetpar.2011.05.031. PMid:21704458.

Esu EB, Effa EE, Opie ON, Meremikwu MM. Artemether for severe malaria. Cochrane Database Syst Rev 2019; 6: CD010678. http:// dx.doi.org/10.1002/14651858.CD010678.pub3. PMid:31210357. 
Fall B, Camara C, Fall M, Nakoulima A, Dionne P, Diatta B, et al. Plasmodium falciparum susceptibility to standard and potential anti-malarial drugs in Dakar, Senegal, during the 2013-2014 malaria season. Malar J 2015; 14(1): 60. http://dx.doi.org/10.1186/ s12936-015-0589-3. PMid:25849097.

Fernando D, Rodrigo C, Rajapakse S. Primaquine in vivax malaria: an update and review on management issues. Malar J 2011; 10(1): 351. http://dx.doi.org/10.1186/1475-2875-10-351. PMid:22152065.

Fichera ME, Roos DS. A plastid organelle as a drug target in apicomplexan parasites. Nature 1997; 390(6658): 407-409. http:// dx.doi.org/10.1038/37132. PMid:9389481.

Florento L, Matias R, Tuaño E, Santiago K, Dela Cruz F, Tuazon A. Comparison of cytotoxic activity of anticancer drugs against various human tumor cell lines using in vitro cell-based approach. Int J Biomed Sci 2012; 8(1): 76-80. PMid:23675259.

Gaillard T, Madamet M, Pradines B. Tetracyclines in malaria. Malar J 2015; 14(1): 445. http://dx.doi.org/10.1186/s12936-0150980-0. PMid:26555664.

Gao F, Zhang X, Wang T, Xiao J. Quinolone hybrids and their anti-cancer activities: an overview. Eur J Med Chem 2019; $165:$ 59-79. http://dx.doi.org/10.1016/j.ejmech.2019.01.017. PMid:30660827.

Ginimuge PR, Jyothi SD. Methylene blue: revisited. J Anaesthesiol Clin Pharmacol 2010; 26(4): 517-520. PMid:21547182.

Gomes TC, de Andrade HF Jr, Lescano SA, Amato-Neto V. In vitro action of antiparasitic drugs, especially artesunate, against Toxoplasma gondii. Rev Soc Bras Med Trop 2012; 45(4): 485-490. http://dx.doi.org/10.1590/S0037-86822012000400014. PMid:22930046.

Gupta N, Srivastava SK. Atovaquone: an antiprotozoal drug suppresses primary and resistant breast tumor growth by inhibiting HER2/ß-catenin signaling. Mol Cancer Ther 2019; 18(10): 1708-1720. http://dx.doi.org/10.1158/1535-7163.MCT-18-1286. PMid:31270151.

Harmse R, Wong HN, Smit FJ, Muller J, Hemphill A, N'Da DD, et al. Activities of 11-azaartemisinin and N-sulfonyl derivatives against Neospora caninum and comparative cytotoxicities. Chem Med Chem 2017; 12(24): 2094-2098. http://dx.doi.org/10.1002/ cmdc.201700600. PMid:29210523.

Harrell M, Carvounis PE. Current treatment of toxoplasma retinochoroiditis: an evidence-based review. J Ophthalmo/ 2014; 2014: 273506. http://dx.doi.org/10.1155/2014/273506. PMid:25197557.

Haussig JM, Matuschewski K, Kooij TW. Inactivation of a Plasmodium apicoplast protein attenuates formation of liver merozoites. Mol Microbiol 2011; 81(6): 1511-1525. http://dx.doi.org/10.1111/j.1365-2958.2011.07787.x. PMid:21848587.

Holfels E, McAuley J, Mack D, Milhous WK, McLeod R. In vitro effects of artemisinin ether, cycloguanil hydrochloride (alone and in combination with sulfadiazine), quinine sulfate, mefloquine, primaquine phosphate, trifluoperazine hydrochloride, and verapamil on Toxoplasma gondii. Antimicrob Agents Chemother 1994; 38(6): 1392-1396. http://dx.doi.org/10.1128/AAC.38.6.1392. PMid:8092843.

Hu YQ, Zhang S, Xu Z, Lv ZS, Liu ML, Feng LS. 4-Quinolone hybrids and their antibacterial activities. Eur J Med Chem 2017; 141: 335-345. http://dx.doi.org/10.1016/j.ejmech.2017.09.050. PMid:29031077.

Kadri D, Crater AK, Lee H, Solomon VR, Ananvoranich S. The potential of quinoline derivatives for the treatment of Toxoplasma gondii infection. Exp Parasitol 2014; 145: 135-144. http://dx.doi.org/10.1016/j.exppara.2014.08.008. PMid:25128801.

Kim JT, Park JY, Seo HS, Oh HG, Noh JW, Kim JH, et al. In vitro antiprotozoal effects of artemisinin on Neospora caninum. Vet Parasitol 2002; 103(1-2): 53-63. http://dx.doi.org/10.1016/S0304-4017(01)00580-5. PMid:11751000.

Krettli AU. Antimalarial chemotherapy. Mechanisms of action, resistance, and new directions in drug discovery. Mem Inst Oswaldo Cruz 2001; 96(8): 1185-1186. http://dx.doi.org/10.1590/S0074-02762001000800028.

Lelièvre J, Almela MJ, Lozano S, Miguel C, Franco V, Leroy D, et al. Activity of clinically relevant antimalarial drugs on Plasmodium falciparum mature gametocytes in an ATP bioluminescence "transmission blocking" assay. PLoS One 2012; 7(4): e35019. http:// dx.doi.org/10.1371/journal.pone.0035019. PMid:22514702.

Lindsay DS, Dubey JP. Evaluation of anti-coccidial drugs' inhibition of Neospora caninum development in cell cultures. J Parasitol 1989; 75(6): 990-992. http://dx.doi.org/10.2307/3282884. PMid:2614609.

Lindsay DS, Rippey NS, Cole RA, Parsons LC, Dubey JP, Tidwell RR, et al. Examination of the activities of 43 chemotherapeutic agents against Neospora caninum tachyzoites in cultured cells. Am J Vet Res 1994; 55(7): 976-981. PMid:7978638.

Luzzi GA, Peto TE. Adverse effects of antimalarials: an update. Drug Saf 1993; 8(4): 295-311. http://dx.doi.org/10.2165/00002018199308040-00004. PMid:8481216.

Marugan-Hernandez V. Neospora caninum and bovine neosporosis: current vaccine research. J Comp Patho/ 2017; 157(2-3): 193200. http://dx.doi.org/10.1016/j.jcpa.2017.08.001. PMid:28942304. 
Mather MW, Darrouzet E, Valkova-Valchanova M, Cooley JW, McIntosh MT, Daldal F, et al. Uncovering the molecular mode of action of the antimalarial drug atovaquone using a bacterial system. J Biol Chem 2005; 280(29): 27458-27465. http://dx.doi. org/10.1074/jbc.M502319200. PMid:15917236.

McFadden DC, Seeber F, Boothroyd JC. Use of Toxoplasma gondii expressing beta-galactosidase for colorimetric assessment of drug activity in vitro. Antimicrob Agents Chemother 1997; 41(9): 1849-1853. http://dx.doi.org/10.1128/AAC.41.9.1849. PMid:9303372.

Mendorf A, Klyuchnikov E, Langebrake C, Rohde H, Ayuk F, Regier M, et al. Atovaquone for prophylaxis of toxoplasmosis after allogeneic hematopoietic stem cell transplantation. Acta Haematol 2015; 134(3): 146-154. http://dx.doi.org/10.1159/000380757. PMid:25968483.

Menezes CMS, Kirchgatter K, Di Santi SM, Paula GA, Ferreira El. In vitro evaluation of quinidine sensitivity in brazilian Plasmodium falciparum isolates: comparative analysis to quinine and chloroquine. Rev Inst Med Trop São Paulo 2001; 43(4): 221-226. http:// dx.doi.org/10.1590/S0036-46652001000400009. PMid:11558003.

Morrissette NS, Sibley LD. Cytoskeleton of apicomplexan parasites. Microbiol Mol Biol Rev 2002; 66(1): 21-38. http://dx.doi. org/10.1128/MMBR.66.1.21-38.2002. PMid:11875126.

Mosmann T. Rapid colorimetric assay for cellular growth and survival: application to proliferation and cytotoxicity assays. $J$ Immunol Methods 1983; 65(1-2): 55-63. http://dx.doi.org/10.1016/0022-1759(83)90303-4. PMid:6606682.

Müller J, Aguado A, Laleu B, Balmer V, Ritler D, Hemphill A. In vitro screening of the open source Pathogen Box identifies novel compounds with profound activities against Neospora caninum. Int J Parasito/ 2017; 47(12): 801-809. http://dx.doi.org/10.1016/j. ijpara.2017.06.002. PMid:28751177.

Müller J, Winzer PA, Samby K, Hemphill A. In vitro activities of MMV malaria box compounds against the apicomplexan Parasite Neospora caninum, the causative agent of neosporosis in animals. Molecules 2020; 25(6): 1460. http://dx.doi.org/10.3390/ molecules25061460. PMid:32213892.

Mwanza S, Joshi S, Nambozi M, Chileshe J, Malunga P, Kabuya JBB, et al. The return of chloroquine-susceptible Plasmodium falciparum malaria in Zambia. Malar J 2016; 15(1): 584. http://dx.doi.org/10.1186/s12936-016-1637-3. PMid:27919256.

Negreiros S, Farias S, Viana GMR, Okoth SA, Udhayakumar V, Santelli ACFS, et al. Plasmodium vivax Malaria in Cruzeiro do Sul, Brazil. Am J Trop Med Hyg 2016; 95(5): 1061-1068. http://dx.doi.org/10.4269/ajtmh.16-0075. PMid:27549633.

Neville AJ, Zach SJ, Wang X, Larson JJ, Judge AK, Davis LA, et al. Clinically available medicines demonstrating anti-Toxoplasma activity. Antimicrob Agents Chemother 2015; 59(12): 7161-7169. http://dx.doi.org/10.1128/AAC.02009-15. PMid:26392504.

Ou M, Zhang Z, Wen Y, Yang H, Gu J, Xu X. Cytotoxic study in the treatment of tetracycline by using magnetic Fe $\mathrm{O}_{4}-\mathrm{PAMAM}$ antibody complexes. Environ Chem Lett 2019; 17(1): 543-549. http://dx.doi.org/10.1007/s10311-018-0803-y.

Pearson PA, Piracha AR, Sen HA, Jaffe GJ. Atovaquone for the treatment of toxoplasma retinochoroiditis in immunocompetent patients. Ophthalmology 1999; 106(1): 148-153. http://dx.doi.org/10.1016/S0161-6420(99)90021-0. PMid:9917796.

Pereira LM, de Luca G, Abichabki NLM, Bronzon da Costa CM, Yatsuda AP. Synergic in vitro combinations of artemisinin, pyrimethamine and methylene blue against Neospora caninum. Vet Parasitol 2018; 249: 92-97. http://dx.doi.org/10.1016/j. vetpar.2017.11.014. PMid:29279093.

Pereira LM, Mota CM, Baroni L, Bronzon da Costa CM, Brochi JCV, Wainwright M, et al. Inhibitory action of phenothiazinium dyes against Neospora caninum. Sci Rep 2020; 10(1): 7483. http://dx.doi.org/10.1038/s41598-020-64454-x. PMid:32366934.

Pereira LM, Vigato-Ferreira IC, de Luca G, Bronzon da Costa CM, Yatsuda AP. Evaluation of methylene blue, pyrimethamine and its combination on an in vitro Neospora caninum model. Parasitology 2017; 144(6): 827-833. http://dx.doi.org/10.1017/ S0031182016002584. PMid:28073383.

Pereira LM, Yatsuda AP. The chloramphenicol acetyltransferase vector as a tool for stable tagging of Neospora caninum. Mol Biochem Parasitol 2014; 196(2): 75-81. http://dx.doi.org/10.1016/j.molbiopara.2014.08.001. PMid:25127750.

Ramya TN, Mishra S, Karmodiya K, Surolia N, Surolia A. Inhibitors of nonhousekeeping functions of the apicoplast defy delayed death in Plasmodium falciparum. Antimicrob Agents Chemother 2007; 51(1): 307-316. http://dx.doi.org/10.1128/AAC.00808-06. PMid:17060533.

Reichel MP, Alejandra Ayanegui-Alcerreca M, Gondim LF, Ellis JT. What is the global economic impact of Neospora caninum in cattle - the billion dollar question. Int J Parasitol 2013; 43(2): 133-142. http://dx.doi.org/10.1016/j.jpara.2012.10.022. PMid:23246675.

Reichel MP, McAllister MM, Pomroy WE, Campero C, Ortega-Mora LM, Ellis JT. Control options for Neospora caninum - is there anything new or are we going backwards? Parasitology 2014; 141(11): 1455-1470. http://dx.doi.org/10.1017/S0031182014000158. PMid:24667014. 
Reid AJ, Vermont SJ, Cotton JA, Harris D, Hill-Cawthorne GA, Konen-Waisman S, et al. Comparative genomics of the apicomplexan parasites Toxoplasma gondii and Neospora caninum: coccidia differing in host range and transmission strategy. PLoS Pathog 2012; 8(3): e1002567. http://dx.doi.org/10.1371/journal.ppat.1002567. PMid:22457617.

Sánchez-Sánchez R, Ferre I, Re M, Vázquez P, Ferrer LM, Blanco-Murcia J, et al. Safety and efficacy of the bumped kinase inhibitor BKI-1553 in pregnant sheep experimentally infected with Neospora caninum tachyzoites. Int J Parasitol Drugs Drug Resist 2018a; 8(1): 112-124. http://dx.doi.org/10.1016/j.ijpddr.2018.02.003. PMid:29501973.

Sánchez-Sánchez R, Vázquez P, Ferre I, Ortega-Mora LM. Treatment of toxoplasmosis and neosporosis in farm Ruminants: state of knowledge and future trends. Curr Top Med Chem 2018b; 18(15): 1304-1323. http://dx.doi.org/10.2174/15680266186661810 02113617. PMid:30277158.

Sanders NG, Meyers DJ, Sullivan DJ. Antimalarial efficacy of hydroxyethylapoquinine (SN-119) and its derivatives. Antimicrob Agents Chemother 2014; 58(2): 820-827. http://dx.doi.org/10.1128/AAC.01704-13. PMid:24247136.

Schuck DC, Ferreira SB, Cruz LN, Rocha DR, Moraes MS, Nakabashi M, et al. Biological evaluation of hydroxynaphthoquinones as anti-malarials. Malar J 2013; 12(1): 234. http://dx.doi.org/10.1186/1475-2875-12-234. PMid:23841934.

Secrieru A, Costa ICC, O’Neill PM, Cristiano MLS. Antimalarial agents as therapeutic tools against toxoplasmosis: a short bridge between two distant illnesses. Molecules 2020; 25(7): 1574. http://dx.doi.org/10.3390/molecules25071574. PMid:32235463.

Staines HM, Burrow R, Teo BH, Chis Ster I, Kremsner PG, Krishna S. Clinical implications of Plasmodium resistance to atovaquone/ proguanil: a systematic review and meta-analysis. J Antimicrob Chemother 2018; 73(3): 581-595. http://dx.doi.org/10.1093/jac/ dkx431. PMid:29237012.

Sullivan DJ Jr, Gluzman IY, Russell DG, Goldberg DE. On the molecular mechanism of chloroquine's antimalarial action. Proc Natl Acad Sci USA 1996; 93(21): 11865-11870. http://dx.doi.org/10.1073/pnas.93.21.11865. PMid:8876229.

Takala-Harrison S, Laufer MK. Antimalarial drug resistance in Africa: key lessons for the future. Ann N Y Acad Sci 2015; 1342(1): 62-67. http://dx.doi.org/10.1111/nyas.12766. PMid:25891142.

Thybo S, Gjorup I, Ronn AM, Meyrowitsch D, Bygberg IC. Atovaquone-proguanil (malarone): an effective treatment for uncomplicated Plasmodium falciparum malaria in travelers from Denmark. J Travel Med 2004; 11(4): 220-223. http://dx.doi. org/10.2310/7060.2004.19005. PMid:15541224.

Touré AO, Koné LP, Jambou R, Konan TD, Demba S, Beugre GE, et al. In vitro susceptibility of $P$. falciparum isolates from Abidjan (Côte d'Ivoire) to quinine, artesunate and chloroquine. Sante 2008; 18(1): 43-47. http://dx.doi.org/10.1684/san.2008.0103. PMid:18684691.

Uddin T, McFadden GI, Goodman CD. Validation of putative apicoplast-targeting drugs using a chemical supplementation assay in cultured human malaria parasites. Antimicrob Agents Chemother 2017; 62(1): e01161-e17. http://dx.doi.org/10.1128/aac.01161 17. PMid:29109165.

Wadi I, Pillai CR, Anvikar AR, Sinha A, Nath M, Valecha N. Methylene blue induced morphological deformations in Plasmodium falciparum gametocytes: implications for transmission-blocking. Malar J 2018; 17(1): 11. http://dx.doi.org/10.1186/s12936-0172153-9. PMid:29310655.

Wang R, Xu K, Shi W. Quinolone derivatives: potential anti-HIV agent-development and application. Arch Pharm 2019; 352(9): e1900045. http://dx.doi.org/10.1002/ardp.201900045. PMid:31274223.

Woodward RB, Doering WE. The total synthesis of quinine. J Am Chem Soc 1945; 67(5): 860-874. http://dx.doi.org/10.1021/ ja01221a051.

Ye Z, Van Dyke K. Interaction of artemisinin and tetracycline or erythromycin against Plasmodium falciparum in vitro. Parasite 1994; 1(3): 211-218. http://dx.doi.org/10.1051/parasite/1994013211. PMid:9140487. 